\title{
Osmanlı Nüfus Politikaları Açısından Çocuk Düşürme Olgusu
}

\section{The Phenomenon of Abortion from the state point of Ottoman Population Policy}

\section{Fatma ŞİMŞEK*}

Öz: Osmanlı İmparatorluğu'nda 19. yüzyılın ikinci yarısına kadar Iskat-1 cenin (çocuk düşürme), devletin din ekseninde (Şer'i hukuk) kapsamında ele aldığı konulardan biri idi. İslamiyet diğer dinlerde olduğu gibi çocuk düşürmeyi kesinlikle yasaklamış, ancak bazı fikıh ekollerinde annenin hayatı tehlikede ise cenin 40 veya 120 günlük iken alınmasına müsaade edilmişti. Bununla birlikte Tanzimat sonrasında Osmanlı Devlet anlayışındaki ve uygulamalarındaki değişim ile birlikte toprak kayıpları, meselenin farklı şekillerde ele alınmasını zorunlu kıldı. Süregelen savaşlar ve sonucunda yaşanılan kayıpların yanı sıra nüfusun ve yoğunluğunun azalmasına neden olan diğer önemli etkenler ise yaşanan salgınlar ve olumsuz yaşam koşullarıydı. Bu nedenle devlet, 1skat-1 cenin meselesini, daha dünyevi bir alanda ve ihtiyaçları (asker-vergi) ekseninde ele almaya başladı. Bunu yaparken de nüfusun sadece sayısal çoğalmasıyla değil daha sağlıklı ve nitelikli olması yönüyle de ilgilenmekteydi. Bu bağlamda hiç şüphesiz resmi söylemde, kadının ve rolünün tanımlanmasında doğurganlığına toplumsal-siyasal bağlamda daha çok vurgu yapılmaktaydı. Ancak sorunun, devlet adamları tarafindan ele alınmasında ve 1skat-1 ceninin önlenmesi için öne sürülen gerekçelerde "günah" vurgusu dolayısıyla dini motiflerin kullanımı sürekli ön planda olacaktı. Bu noktadan hareketle çalışmamızda ıskat-1 cenin konusu, devletin nüfus politikaları çerçevesinde belgelere yansıyan vakalarla birlikte ele alınmaya çalışılacaktır.

Anahtar sözcükler: Osmanlı İmparatorluğu, Şer’i Hukuk, Nüfus Politikası, Çocuk üşürme

\begin{abstract}
Until the second half of the $19^{\text {th }}$ century, abortion in the Ottoman Empire was one of the issues that the state considered a part of the sharia. As in other religions, abortion is completely forbidden in Islam but according to some schools of fiqh with the exception of the mother's life being in danger; in that case, abortion was allowed until the foetus's age of 40-120 days. After Tanzimat, which brought changes to the Ottoman State, the matter was dealt with differently. Ongoing wars and the resulting losses of land and people, furthermore outbreaks of disease and poor living conditions in general, caused a decline of the population. For this reason, the Ottoman state began to handle the problem on a secular basis, considering the state's needs in terms of taxes and military. The state was consequently not only interested in a quantitative growth of the population, but rather in a qualitative improvement of the peoples' state of health. In this context, the formal discourse shifted to the fertility of women and thereby, the roles of women in social and political contexts were being (re-)defined. However, even when abortion was a matter of the state, religious norms were being used to emphasise the notion of "sin" in trying to prevent a rise in the number of abortions. Our approach to this topic is to reflect on the framework given by the Ottoman state's population policy on the basis of state documents.
\end{abstract}

Keywords: Ottoman Empire, Ecclesiastical Court, Population Policy, Abortion

\footnotetext{
*Yrd. Doç. Dr., Akdeniz Üniversitesi, Edebiyat Fakültesi, Tarih Bölümü, Antalya. fsimsek@akdeniz.edu.tr
} 
Nüfus ve bu bağlam içerisinde üremek olgusu tarih boyunca tüm dinler ve devletler tarafından ele alınan konulardan biri olmuştur. Özellikle askeri ve iktisadi gücün kaynağı olarak görülen nüfusun artması için, dinler inananlarına ve devletler uyruklarına çoğalmalarını teşvik ederek üremeyi özendirmişlerdir. Üremenin sistemli olarak devam ettirilmesinin ve doğan çocukların yetiştirilmesinin en iyi formülü ise evlilik ve dolayısıyla aile idi. Bu nedenle gerek dinler ve gerek siyasal yapılar, toplumun temel direği olarak gördükleri ailenin kurulması ve korunmasına büyük önem vererek, çocuklu ailelere bazı kolaylıklar ve mükâfatlar sağlamışlardı. Örneğin Roma miras hukukunda bekar ve çocuksuz kadınların paylarının evli mirasçılara veya devlete intikal etmekteydi (Berki 1970, 542-576). Nüfusun artışını olumsuz etkileyecek her türlü eylem ve tedbir ise kesinlikle yasaklanmış hatta birtakım cezalar ve tehditlerle bunların önüne geçilmeye çalışılmıştır (Aydın 1993, 363). Iskatı engellemek için Kur-an'daki bazı hükümler dikkati çeker, yoksulluk korkusuyla 1skata yönelmenin yanlış olduğu, Enam süresinde (6/51) de "Fakirlik korkusu sebebiyle çocuklarınızı öldürmeyiniz. Sizlere de onlara da rıkk biz veriyoruz", Ísra süresinde (17/31) de "Onları öldürmek gerçekten büyük günahtır" denerek bu suçları işlememeleri için müminler uyarılmaktaydı (Dölek 2009, 75-77).

Osmanlı Devleti’nin özellikle de klasik dönem devlet anlayışına ve uygulamalarına baktığımızda nüfus ve üremeyle ilgili aslında yukarıda değindiğim esaslardan çok da farklı bir manzara ile karşılaşmayız. Bizatihi devletin kuruluşunda ve gelişmesinde büyük rol oynamış gaza inanışı gereği, Osmanlı Devleti zihniyetinde nüfus denince haliyle ilk akla gelen savaşçı olan erkek nüfustu. Savaş, Osmanlı devleti için sadece askeri ve siyasi bir olgu değil aynı zamanda yeni iktisadi alanların açılması ve bu alanların toplumda yeniden paylaştırılması anlamlarına geldiğinden erkek nüfus çok önemliydi. Osmanlı devlet fonksiyonlarını formüle eden daire-i adalette bile leşker-reaya, mal-devlet ilişkileri üzerinde durulması aslında nüfus hakkında Osmanlı'nın tavrını çok iyi sergilemekteydi. Erkek nüfusun değerini artıran bir diğer önemli faktör ise iktisadi alandaki etkinlikleri idi. Dolayısıyla savaşçılıklarının yanı sıra hem zenginliğin üretilmesi hem de bu üretimden doğan vergilendirmede devlet tarafindan muhatap alınanın erkek olması, Osmanlı tahrir ve tımar defterlerinin mahiyetini belirlemiştir. Çünkü bunlar 15. ve 16. yüzy1ldaki tahrirler, vergi ödeyen yetişkin erkeklerin ellerinde işledikleri topraklarıyla birlikte kaydedildiği defterlerdi (Çoşgel 2004, 87-88).

Sadece nüfusun sayısal üstünlüğü değil aynı zamanda bu nüfusun iktisadi-sosyal ve askeri yönlerden işlevsel (verimli) hale getirilmesi ve üzerinde etkili bir denetim mekanizmasının kurulması da siyasi iktidarlar için hayati öneme sahiptir. Osmanlı Devleti tüm bu değindiğim esasları gerçekleştiren iki önemli araca sahipti. Bu araçlar kentlerde lonca, taşrada ise tımar teşkilatıydı. Diğer taraftan özellikle Rumeli'de fetihlerin başlamasından sonra devletin politikalarına bakıldığında yeni fethedilen yerlere kendi idari-iktisadi sistemini yerleştirmek üzere iskan-sürgün yöntemlerini başarılı bir şekilde uyguladığı görülür (Barkan, 1942). Bu yöntemler sadece yeni fethedilen yerler değil, güvenlik ve iktisadi kaygılarla üretimin azaldığ 1 veya asayiş sorunlarının yaşandığ yerlerde de uygulanmış ve belirli aralıklarla yapılan tahrirlerle denetim altına alınmaya çalışılımıştır. Hiç kuşkusuz bölgenin nüfus ve mülkiyet ilişkilerini bazen kökten bazen de kısmen değiştiren bu uygulamalar, otoritenin kurulmasını ve sürdürülebilirliğini kolaylaştırmıştır.

Nüfusun bir diğer yarısı olan kadınlar konusuna gelince, maalesef belgeler ve defterler bize bu konuda hiç de bönkür değillerdir.

Yukarıda değindiğim denge ve düzen 16. yüzyıldan itibaren değişmeye başlayacak ve bu dönüşüm belgelere, dönemin kroniklerine ve risalelerin satırlarına canlı bir şekilde yansıyacaktı. Tahrir defterleri, köy ve hane sayılarının arttı̆gını, "Kitab-ı Müstetab" gibi bazı dönemin eserle- 
rinde bekar ve işsiz erkeklerin (suhte ve celali isyanları) asayiş ve iktisadi sorunlara yol açtığını bildirmekteydiler (Yücel 1974, 8-14, 25-27). Tüm bunlar bir nüfus artışına işaret etmekteydi. Keza Fernand Braudel de çalışmasında Akdeniz ve havzasında aynı dönemde bir nüfus artışından bahsetmektedir (Braudel 1989, 365). Tarımsal üretimin en önemli ekonomik etkinlik olduğu toplumlarda fazla nüfusu istihdamı önemli bir sorundu ve yeni tarım alanlarına ihtiyaç vardı bu ise yeni fetihleri zorunlu kılmaktaydı. Ancak talih Osmanlı aleyhine dönmüş, savaşlar artık zafer yerine yenilgiler ile hatta büyük toprak kayıpları ile sonuçlanmaktaydı. Tüm bunlar ise öncesinde tümüyle merkezin inisiyatifinde gerçekleşen nüfus hareketlerini kontrolsüzleştirdiğinden köylerden kentlere, kaybedilen topraklardan ülkeye büyük göç dalgaları, Osmanlı Devleti'nin düzenini altüst edip varolan sorunları daha da şiddetlendirdi. Osmanlı devleti süreç içerisinde bu sorunlarla baş edebilmek için bazı mali, iktisadi ve idari tedbirler alsa da ideal ve sorunsuz işleyen düzen çoktan geride kalmıştı.

Osmanlı'nın nüfus algısına değindikten sonra nüfusun artmasını engellediği gerekçesiyle 1skat-1 cenini nasıl algılamaktaydı? 19. yüzyılın ikinci yarısına kadar 1skat-1 cenin devletin din ekseninde kapsamında ele aldığ 1 konulardandı. O zaman aklımıza İslamiyet'in 1skat-1 cenine yaklaşımı nasıldı sorusu gelmektedir. Annesinin karnında gerçekte görünmediği için "örtülmüş çocuk" anlamında ceninin korunması, İslamiyet'te neslin korunması açısından elzemdi (Çeker 2004, 31). Çocuk düşürmeyle ilgili fikıh ekollerinin farklı yaklaşımları söz konusudur. Hanefi mezhebine göre cenin ruh kazanmadan önce anne karnına düştükten ilk 120 gün (Karaman 1988, 556; 2002, 84), Malikilere göre ise, ilk 40 gün içerisinde annenin hayatı tehlikesi var ise 1skat mekruhtur (Çeker 1993, 364; Konan 2008, 322). Ancak bazı ulema kesiminin görüşü ise insanın yaşam hakkının Allah tarafından döllenmenin gerçekleştiği andan itibaren verildiğini dolayısıyla ebeveyn de olsa hiç kimsenin buna karışamayacağıdır (Köse 2009, 50; Dölek 2009, 72). Yine de kasitlı olarak veya başka gerekçelerle çocuk düşürülmesi (kürtaj) durumunda ise gurre (kadın veya erkek bir köleyi azat etmektir) vermek gerekirdi. Bu da beş deve bedeli yani bin dirhem idi. Düşürülen çocuğun cinsiyeti miktarı etkilemezdi (Çeker 2004, 151; Dölek 2009, 71).

Osmanlı'ya dönecek olursak 1skat-1 cenin gibi mahrem ve genellikle gizli saklı yapılan bu eylemlerin, belgelerde nasıl ve hangi gerekçelerle geçtiğini ortaya koymak, devletin ve tarafların tavırlarının belirlenmesi açısından da gereklidir. Konunun gündeme gelmesinin en önemli nedenlerinden birinin şikâyet mekanizması olduğu anlaşılmaktadır. Hangi kesimlerin şikayetçi olduklarına baktığımızda; Amasya'ya bağlı Merzifon kazası, Rumcuk karyesinde üç aylık hamile karısıyla tarlada çalışırken Kör Ömer ve Deli Ali adlı kişilerin saldırdıklarını ve karısının düşük yaptığ 1 gerekçesiyle Salih (BOA, A.MKT.DV. 135 / 44), Kütahya'da Meydan mahallesinde komşusunun korkutması nedeniyle zevcesi Şerife'nin çocuğunu düşürdüğüne dair Molla Mustafa (Güngör 2006, 166), Selanik'te Hacı Kasım mahallesinde evinde misafir ettiği kişilerin hamile karısına tecavüzleri nedeniyle çocuğunun düştüğünü söyleyen Tavcı Mustafa (BOA, DH.EUM.AYS. 61 / 48), Kayseri Develi' de evini basıp hamile karısını dövmeleri ile düşük yapan karısı nedeniyle Hacı Ömer'den şikayetçi olan Enis Bey (BOA, A.MKT.DV. 130 / 61) gibi örneklerden görüleceği üzere genellikle kadının kocası tarafından gündeme getirilmekteydi. Şikayetin genellikle kocalar tarafından gündeme getirilmesinin nedenleri, kadınların ya düşük nedeniyle sağlık durumlarının buna el vermemeleri ya da mahkeme gibi bir kurumda yaşanılan durumdan duydukları utanç nedeniyle kocalarının kendilerini daha etkili ifade edecekleri düşünmüş olmalılar.

Ancak bazı durumlarda ise kocalar, karılarından ıskat-1 cenine başvurdukları için şikayetçi olabilmekteydiler. Konuyla ilgili olarak elimizdeki en eski (6 Ramazan 1179) 16 Şubat 1766 
tarihli belge bu konuda ilginç bilgiler vermektedir. İznikmit sakinlerinden Ebubekir'in kendisinin haberi olmadan üç defa çocuk düşürdügü gerekçesiyle karısı Ayşe'yi mahkemeye vermiş ve karısından dem (kan) baha talep etmiştir (BOA, C.ADL. 80 / 4825). Burada yukarıda değinildiği üzere diyetini istemekteydi. Belgede, Ebubekir'in düşüklerden nasıl haberdar olduğu, eşini neden şikayet ettiği, talebinin yerine getirilip getirilmediği gibi soruların cevaplarını bulmak imkansız. Ancak Ebubekir karısının toplumsal saygınlığını böylesi bir suçlamayla zedeleyeceği muhakkaktı. Bazen ise Kirmastı Kaymakamı Süleyman Ruf Bey (BOA, İ.AZN. 66 / 1324 R-01) ve Makriköy'den Abdülvehap Efendi (BOA, DH.EUM.AYS. 61 / 27) örneklerinde olduğu gibi 1skatta yardımcı oldukları gerekçesiyle kocaların, karılarıyla birlikte dava edilmekteydiler.

Şikayet mekanizmasını etkili şekilde işleten kesimlerden bir diğeri ise olayların yaşandığı yerlerdeki devletin resmi görevlileri olarak idarecilerdi. Nüfusun çoğalması için çaba harcayan bu kesim, yönetimindeki bölgelerde yaşanan vakalar ve olaylardan bir şekilde yetkili olarak haberdar olmakta ve şikayet konusu yapabilmekteydiler. Örneğin Limnili Dimitri ve karısının 1skat-1 cenine yardım ettikleri gerekçesiyle cezalandırılmalarını talep eden Selanik Valisi Ahmet (BOA, A.MKT.UM. 242 / 19) örneklerden biriydi. Şikayet konusu olayların gerçekliğinin araştırılması için vazgeçilmez yöntemlerden biri keşifti ve mahalli ebeler keşif esnasında bilirkişi olarak görevlendirilmekteydiler (Güngör 2006, 166).

Iskat-1 cenin kapsamında ele alınması gereken hiç şüphesiz bir diğer önemli konu, bu eylem esnasında hayatını kaybeden kadınlardı. Nitekim doğmamış bir neslin katli kadar bu eylem esnasında ölen kadınların, toplum ve aileler açısından büyük bir kayıp olduğu ortada idi. Kaldı ki neslin sağliklı yetiştirilmesi açısından annelerin de sağlığı önemliydi. Bu nedenle konuyla ilgili sunulan arzlarda; 1skat-1 cenin kadar bu suçu işlerken hayatını kaybeden veya sakat kalan kadınlar üzerinde de durulmaktaydı. 13 Zilkade 1307 (1 Temmuz 1890) tarihli sunulan arzda; teşebbüs eden kadınlardan yirmide dördünün hayatını kaybettiği ileri sürülmekte şüpheli yeni doğan ya da kadın ölümlerinde ölüm sebebinin ıskat-1 cenin olup olmadığına dair tıbbi rapor verilmediği sürece cenazelerin kaldırılmaması istenmekteydi (BOA, İ.DAH. 1185 / 92723; BOA, C.ADL. 108, 9 M 1254 [4 Nisan 1838] ). “...evlad-ı nimetinin kadr-l klymetini” (BOA, C.SH. 1 / 30615 Ş 1254 [3 Kasım 1838]; BOA, C.ADL. 1089 M 1254 [4 Nisan 1838]) bilmeyen bu kadınların asla rıza gösterilemeyen bir eylem esnasında ölümleri "kendileri telef olmak misillümüstehak-ı bela olageldikleri" şeklinde hak ettikleri cezayı bulduklarına dair olumsuz ifadeler ise dikkati çekmektedir (BOA, C.SH. 566, 13 Za 1254 [28 Ocak 1839]; BOA, C.DH. 13 N 1254 [30 Kasim 1838]; BOA, C.DH. 6563, 3 Za 1254 [18 Ocak 1839]).

Neslin devamı açısından çocuk yapmak o denli önemliydi ki, kadınlığın sadece bu yönüyle tanımlanması bir yana toplum açısından büyük zararları olduğu gerekçesiyle farklı cinsel eğilimlerin bile bu açıdan ele alınmasına ve menedilmesine şaşmamak gerekir. "Osmanlıda Kadınlığın Durumu" adlı eserde; kadın kadına cinselliği "sevicilik" veya erkek erkeğe cinselliği ise "mahbubseverlik" diye niteleyen yazar; bunların da annelikten ve babalıktan uzaklaşmaları nedeniyle çocuk yapmaktan kaçındıklarını ileri sürer (Asım 1989, 57-58).

Dini ve idari otoriteler tarafından sürekli olarak menedilen hatta çocuk düşürenlere veya bu işe yardımcı olanlara verilen cezalara rağmen kadınlar, canları pahasına neden bu yönteme başvurmaktaydılar? Bu sorunun cevabını paradoksal bir şekilde ıskat-1 cenini yasaklayan fermanlardan, konuyla ilgili görevlendirilen kişilerin raporlarından almak mümkündür. Yoksulluk ve geçim sıkıntısı gerekçelerden en yaygın olanıydı. Buna göre; iki veya üç çocuk sahibi olduktan sonra ebeveynlerin "bar-ızdırab altında bırakmamak" için bu yönteme başvurdukları bildirilmektedir (BOA, Y.TPK.AZJ, 46 / 19). Nitekim Bayburt'un Cami mahallesinde Hamal Salih'in zevcesi Pembe, fazla çocuk sahibi olması ve fakirlikten dolayı çocuğunu düşürmesi (Gül 2013, 
11) yaşanan sayısız örneklerden sadece biriydi. Yoksulluk nedeniyle iskat-1 cenin vakalarının önlenmesi için askerlik hizmetinde bulunmuş olanlara altı/yedi çocuk yaptıkları takdirde devletten maaş bağlanması gibi bir takım öneriler getirilmişti (BOA, Y.TPK.AZJ, 46 / 19). Yapılan bu önerilerle getirilen çözüm, bir defada ikiz veya daha fazla çocuk sahibi olan yoksul ailelere aylık ödenen "tev'emmaaşı"na benzer bir çözüm getirmekteydiler (Dinç, Şimşek \& Eroğlu 2009). Söz konusu maaşların gerçekten ihtiyaç sahiplerine tahsisi için başvuruların titizlikle incelenmesi özellikle vurgulanmaktaydı (BOA, İ.DAH. 95051, 8 Kanun-i evvel 1308 [20 Aralık 1892]).

Osmanlı'da konu ile ilgili verilen cezalara bakacak olursak sskat-1 cenini gerçekleștirenlere veya bunlara yardımcı olanlara genellikle hapis, para (diyet) (BOA, A.MKT.UM. 396 / 66, 23 B 1276 [15 Şubat 1860]), kürek veya sürgün (BOA, A.MKT. 242 / 19029 L 1272 [3 Temmuz 1856]; BOA, İ.MVL. 271 / 10.465, 21 B 1269 [30 Nisan 1853]) cezalarının verildiğini görmekteyiz. Dikkati çeken bir başka konu ise bazı belgelerde ise bu suçu işleyenlerin en ağır cezalarla cezalandırılacakları bildirilmekteyse de cezaların ne olacağı ile ilgili herhangi bir bilgi verilmemesiydi (BOA, C.ADL. 896, 23 N 1254 [10 Aralık 1838]; BOA, C.ADL. 4825, 27 L 1254 [13 Ocak 1839]). Bu işlerle uğraşan yabancı uyruklu ise bir an önce sınır dışı edilmekteydi. Örneğin aslında Rus uyruklu olup alman pasaportu taşıyan Zibold'un sınır dış1 edilmesi hükümeti epey uğraştırmıştı (BOA, Y.A.HUS. 481 / 76, 16 N 1322 [24 Kasım 1904]; BOA, İ.HUS. 121 / 1322 L-32, 7 L 1322 [4 Eylül 1904]; BOA, İ.HUS. 122 / 1322 Ş-11, 4 Şubat 1322 [17 Şubat 1907]; BOA, İ.HUS. 124 / 1322 L-32, 7 L 1322 [15 Aralık 1904]). Cezalara rağmen eylemler, bu defa gizli gerçekleştirilmekteydi.

Bununla birlikte Tanzimat'ın hemen öncesinde ve sonrasında Osmanlı Devlet anlayışındaki ve uygulamalarındaki değişim ile birlikte toprak kayıpları, meselenin farklı şekillerde ele alınmasını zorunlu kıldı. Süregelen savaşlar ve sonucunda yaşanılan kayıpların yanı sıra nüfusun ve yoğunluğunun azalmasına neden olan diğer önemli etkenler ise yaşanan salgınlar ve olumsuz yaşam koşullarıyd. Ancak yaşanan bu koşullara rağmen, resmi belgelerde bazen abartılı şekilde ıskat-1 ceninin savaşlardan ve salgınlardan daha fazla nüfusu azalttı̆ğ ileri sürülmekteydi (BOA, Y.TPK.AZJ. 46 / 19). Bu söylem aslında devletin 1skat-1 cenin konusundaki hassasiyetini ve eylemin yaygınlığını göstermesi açısından önemliydi. Fiiliyattaki duruma baktığımızda Gayr-i Müslim nüfus 1830'lardan sonra hızla artmaya başlamıştı. Müslüman nüfus ise 1830'lara kadar azalma, 1850'den itibaren tekrar artış eğilimindedir. Doğum oranlarında Müslümanlar aleyhine bir artış söz konusuydu. Karpat, bunu Türk erkeklerin en verimli çağlarında askerlik yapmalarına, ekonomik nedenlerle evlenip aile kuramamalarına bağlamaktadır (Karpat 2003, 49). Bu nedenle yukarıda değinildiği üzere fiilen askerlik hizmetinde bulunanlara, altı yedi çocuk yaptıkları takdirde devletten maaş bağlanması, askerlik hizmetinden muaf olan İstanbul halkı ile Gayr-i Müslimlerin bundan muaf tutulmaları yolunda teklifler sunulmaktaydı (BOA, Y.TPK.AZJ. 46 / 19). Bu durum Müslüman nüfusun artırılmasına dair düşünceyi ortaya koyması açısından dikkat çekmektedir.

Hayat pahalılığı pek tabii çocuk yapmanın olmaz ise olmaz koşulu olan ve toplumun en önemli yap1 taşı olan evlilikleri de tehdit etmekteydi. Aynı durum Gayr-i müslimler için de geçerliydi. Osmanlı devlet geleneğinde; askerlik sadece Müslüman nüfusun sorumluluğunda olduğundan devlet için özellikle bu kesimin evliliklerinin ve nüfusunun artması önemliydi. Bu sosyal sorunları çözmek için Meclis-i Vala'da 1845 tarihinde alınan bir karara göre evlenmede aşırı masraflar yasaklanmıştı. Abdülmecit döneminde nüfusun artması bakımından evliliklerin kolaylaştırılması için müfettişler görevlendirildi. Bu tedbirler ile aslında doğurganlık çağında kızların evlenmeleri ve böylelikle nüfusun artışı da amaçlanmaktaydı (Serbestoğlu 2014, 262). 
Burada özellikle şuna değinmek gerekir ki, Foucault'un (2002, 249-269) biyopolitika devletin siyasi gücünü hayatın her alanına ve bedene nüfuz ettirmesi fikri- kavramından hareketle kadınların bedenlerinin nüfus politikaları bakımından ele alınması bu araçları belirgin kılmaktadır (Akşit 2010 180). Müdahale-denetim mekanizmaları yoluyla bedeni uyruklaştıran devlet, nüfusun da denetimini sağlayarak bedenleri ve bunlardan oluşan toplumu kendi siyasiiktisadi sistemi ile bütünleştirebilecekti (Işık 2012, 106 ). Hatta günümüzde bazı araştırmacılar; Osmanlı tıbbının gelişimi aşamasında nüfusu tehdit eden kürtaj yöntemlerine vakıf olan mahalli ebelerin sistem dışına itilmelerinin en önemli gerekçesi olarak devletin bu politikasını görmektedirler (Neyinli 2014, 198).

Devlet artık nüfusun artışını sağlamak için bir taraftan sayımları daha sistematik bir şekle sokmakla birlikte toplumu bu yönde kontrol araçlarını da geliştirmeye başlamıştı. Sayımlarda sadece erkek nüfus değil taşınır-taşınmak malların sayımı da yapılmaya başlandı. (Shaw 1983, 70). Bu aslında devletin modernleşme-merkezileşme çabaları içerisinde askeri ve vergi reformları için bir bakıma elzemdi. Zaten sayımın yapılmasıyla ile ilgili gönderilen fermanlarda; başta avarız olmak üzere vergilerin tahsilinde devlet ve halk zor durumda kaldığından, nüfusun bilinmesi gerektiği şeklinde bu açıkça ifade edilmekteydi (Lewis 1996, 91; Lütfi Efendi 1999, 643; Gürbüz 2009, 125-128). Osmanlı geleneksel düzeninde bireylerle devlet arasındaki ilişkilerin ya hiç olmadığ 1 ya da kısıtlı kaldığı alanlar 19. yüzyılda yeni sosyal-idari ve sağlık kurumlarının belirmesiyle birlikte artmaya başlamışırır.

Nüfusun sağlıklı ve sağlam olabilmesi, devletin bundan azami istifadesini sağlayacağından bedenin giderek siyasallaşmaya başladığını görüyoruz. Hijyenin tüm toplumda yaygınlaştırılması, karantina uygulamalarının sıkı sıkıya uygulanması, bu dönemde koruyucu sağlık tedbirlerinin de alınmaya başlanması devlet-siyasi beden arasındaki ilişkinin bir sonucudur. Bu nedenle devletin düzenleyici rolünü de vurgulamak gerekir. Özellikle taşrada hıfz-1 sıhha kurallarına riayet edilmemesi, çocuk düşürmeye neden olduğundan gezici sağlik heyetlerinin halkı bilinçlendirmek üzere görevlendirilmesi talep edilmekteydi (BOA, İ.DAH. 1185 / 92723). Aynı zamanda anne-bebek ölümlerinin yüksek olmasında hijyene dikkat etmeyen eğitimsiz ebelerin de rollerinin olduğu gerekçesiyle (Hamlacı 2017, 24) eğitimli ebelerin yaygınlaştırılması ile hamilelik üzerinde devletin pronatalist politikalarının uygulanması mümkün olacaktı (Ersoy 2015, 184). Bir bakıma tıp, nüfus-beden üzerinde geliştirdiği sıkı bilimsel bağlarla, iktidarın hizmetinde yer alacak ve kolaylıkla siyasal bir müdahale aracı olabilecekti (Faucault 2002, 258). Ayrıca Tanzimat ve sonrasında açılan kız rüşdiyelerinde veya diğer eğitim-öğretim kurumlarında, bu politikalar çerçevesinde yetiştirilen kadınlar, ev-kamusal alanlarda kendilerine öğretilen kalıplara göre yaşayacak ve davranacaklardı (Akşit 2009, 4-5).

Doğum gerçekleşir gerçekleşmez bebeklerin kaydedilmeleri artık yeni doğan ebeveynlerin değil devletin bir parçası olarak görülmekteydi ve devlet bu kayıtları tutmakla yükümlüydü. Devlet nüfusundan azami düzeyde yararlanmak için yalnızca doğumların değil ölümlerin de bu kayıtlara işlenmesini ve kontrollerinin yapılmasını istemekteydi (Gürbüz 2009, 197).

Salgınlarla mücadelede bile 1skata neden olan hastalıklar, hem ahlaki yönden düşüklüğe hem de 1skata neden oldukları gerekçesiyle daha titizlikle ele alınmaktaydı. Askeri Tıp Okulu doktorlarından Celalettin Muhtar, frengi gibi kalıtımsal ve bulaşıcı hastalıkların sosyal yapıya zarar verdiğini belirtir. Frengili kocalarından hastalığı kapan kadınlar arasında çocuk düşürmenin yaygın olduğu ya da yaşayabilenlerinin ise zayıf, solgun, kısa, kambur, aptal ve hastalıklara açık olduğunu bildirmekteydi (Özekmekçi 2010, 91). Burada bedenin nitelik-nicelik bakımından dönüştürülerek sağlıklı bir toplum yaratma mücadelesini görmek mümkündür.

Diğer taraftan kürtaja en azından daha ılımlı yaklaşan Hanefi fıkhına rağmen, 1859 Ceza 
Kanunnamesi'nde tamamıyla yasaklandı (Akşit 2010, 186). Buna göre Ceza Kanunnamesi'nde darp veya başka şekillerde hamile kadınların çocuklarını düşürmelerine neden olanlara şeri olarak "diyet", eğer eylem kasıtlı ise kürek cezasına çaptırılmaları istenmiştir (Öztürk 1987, 201; Somel 2002, 77-78). Fakat bazı mülki ve adli memurların bu esasların uygulanmasına dikkat etmediklerini görmekteyiz. Bu gibi durumları engellemek için gerekli cezaları vermedikleri takdirde kendilerinin şiddetli şekilde cezalandırılacakları tehditkâr bir dil ile bildirilmekteydi. Aksi taktirde "vazife-i diniye ve insaniyelerini ifa etmemiş" sayılacaklan ifadeleri ile memurlara aynı zamanda dini ve sosyal bir sorumluluk yüklenmeye çalışılmaktaydı (BOA, İ.DAH. 95051, 8 Kanun-i Evvel 1308 [20 Aralık 1892]). Diğer taraftan eczacı ve sağlıkçı kesimlere gönderilen emirlerde bu suçun işlenmesine aracilık etmemeleri ve aksi takdirde kendilerinin de cezalandırılacakları bildirilmekteydi (BOA, C.DH. 1790, 5 Za 1254 [20 Ocak 1839]). Hatta bu kesimler üzerinde denetimin sağlanması açısından Gayr-i Müslimlerin kendi din adamlarının Müslimlerin ise İmamlar vasıtasıyla yemin etmeleri istenmekteydi (BOA, C.DH. 1026, Selh-i N 1254 [Kasım 1838]). Görüldüğü üzere sorunun, devlet adamları tarafından ele alınmasında ve 1skat-1 ceninin önlenmesi için öne sürülen gerekçelerde "günah" vurgusu dolayısıyla dini motiflerin kullanımı sürekli ön planda olacaktı.

Nüfusun korunması için toplum içerisinde bazı önlemlerin alındığını ve uygulandığını görmekteyiz. İslam'da evlat edinmek yasak olduğundan büyük çoğunluğu kimsesiz çocuklardan oluşan ancak bazen geçim sıkıntısı yaşayan ailelerin de çocuklarını verdikleri tebenni uygulamasına değinmek gerekir. Gayr-i Müslimler arasında da uygulanan bu yöntemde çocuklar, "inde'z-zafer" veya "ianeden müstağni oluncaya dek" vasi tayin edilen kişide kalmaktaydılar. $\mathrm{Bu}$ vasilere mahkemeden günlük belirli bir nafaka bağlanırdı (Düzbakar 2004, 88-90). Örneğin 8 Temmuz 1838'de Tokat'ta Ömer'in ölümüyle çocuklarına anneleri Zeynep Hatunun'un, yine aynı şehirde 8 Mayıs 1838'de Şemsi ölünce çocuklarının vasisi olarak akrabalarından Şerife'nin görevlendirildiğine dair (Yıldız 2007, 25, 27) Şeriyye sicillerinde konuyla ilgili birçok hükme rastlamak mümkündür. Bu çerçevede Nadir Özbek, II. Abdülhamit döneminde açılan darülaceze bünyesinde kurulan ırzahaneler (kreş), eytamhaneler ve diğer hayır kurumlarını, padişahın halkına merhamet duygusunun ön plana çıkarılıp halkın gözünde adeta bir baba kişiliğine bürünme gayretleri olarak değerlendirmektedir (Özbek 2008, 135-136). Bununla birlikte yukarıda değinildiği üzere uygulanan tev'em maaşı da yine bu çerçevede ele alınması gereken uygulamalardan biriydi.

\section{Sonuç}

Osmanlı'da 1skat-1 cenin mevzusunu ele alırken, devletin resmi söyleminin ve politikalarının yansıdığı belgeleri veya dönemin bazı dini ve hukuki eserlerini temel almak zorundayız. Bireylerin, kendileri veya günlük hayatlarına dair tuttukları kayıtların çok nadir hatta neredeyse yok denecek kadar az olması tarihçilerin bireylerin hayatlarına dokunmalarını zorlaştırmaktadır. Toplumun mahrem ve sessiz kalmış aktörlerinden kadınların hayatlarını kurgulamak veya 1skat ya da kürtaj gibi dinin, toplumun ve devletin yasakladığı böylesi bir eylemin dönemin kadınları, kocaları ve aileleri açısından ne ifade edip etmediğini ortaya koymak kısmında işler daha da zorlaşır. Tam da bu noktada devletin resmi satırlarında konuyla ilgili anlatılan vakaların ne derece gerçeği ve yaşanılanları yansıttığı sorusu zihnimizi sürekli meşgul ederken, anlatılardan ziyade aslında anlatılamayanın peşinde belki de kurgu bir dünya ve kuru bir neden-sonuç ilişkisi kurmaya çabalamaktayız. 


\section{KAYNAKÇA}

Ahmet Lütfi Efendi (1999). Vak'anüvis Ahmed Lütfi Efendi Tarihi. İstanbul 1999.

Akşit E. E. (2009). "Osmanlı İmparatorluğu ve Türkiye'de Kamusallık Kavramının Dönüşümü ve Dışladıkları". Ankara Üniversitesi Siyasal Bilgiler Fakültesi Dergisi 64/1 (2009) 1-21.

Akşit E. E. (2010). "Geç Osmanlı ve Cumhuriyet Dönemlerinde Nüfus Kontrolü Yaklaşımları". Toplum ve Bilim 117 (2010) 179-197.

Asım S. (1989) Osmanlı'da Kadınlığın Durumu. İstanbul 1989.

Aydın M. A. (1993). “Çocuk Düşürme”. İslam Ansiklopedisi 8 (1993) 365.

Barkan Ö. L. (1942). "İstila Devirlerinin Kolonizatör Türk Dervişleri ve Zaviyeleri”. Vakıflar Dergisi 2 (1942) 279-304.

Berki Ş. (1970). "Roma'da Miras Hukuku”. Ankara Üniversitesi Hukuk Fakültesi Dergisi 10/1 (1970) 542-576.

Beyinli G. (2014). Elleri Tulsıml Modern Türkiye'de Ebelik. Ankara 2014.

Braudel F. (1989). Akdeniz ve Akdeniz Dünyası. İstanbul 1989.

Çeker O. (1993) “Çocuk Düşürme”. İslam Ansiklopedisi 8 (1993) 365.

Çeker O. (2004). Çocuk ve Hakları. İstanbul 2004.

Çoşgel M. M. (2004). “Ottoman Tax Registers (Tahrir Defterleri)”. Historical Methods 37 (2004) 87-100.

Dinç G., Şimşek F. \& Eroğlu H. (2009). “Osmanlı İmparatorluğu'nda Tev’em Maaşı”. Uludağ Üniversitesi-Fen-Edebiyat Fakültesi Sosyal Bilimler Dergisi 10/16 (2009) 77-100.

Dölek A. (2009). "Ayetler ve Hadisler Işı̆ı̆ında Çocuğun Yaşam Hakkının Korunması". Atatürk Üniversitesi Illahiyat Fakültesi Dergisi 31 (2009) 61-82.

Düzbakar Ö. (2004). "Kimsesiz Çocuklar ve Çocuk Haklarının Korunmasına İlişkin Bursa Şer'iyye Sicillerine Yansiyan Örnekler ”. Uludağ Üniversitesi Fen-Edebiyat Fakültesi Sosyal Bilimler Dergisi 6 (2004) 87-95.

Ersoy G. B. (2002). Kahraman Doktor İhtiyar Acuzeye Karşı, Geç Osmanlı Doğum Politikaları. İstanbul 2015.

Foucault M. (2002). Toplumu Savunmak Gerekir. İstanbul 2002.

Gül A. (2013). "Osmanlı Taşrasında Suç ve Suçlular (1919 Ocak Ayı Erzincan Sancağı Örneği)". EÜHFD 17/1-2 (2013) 1-28.

Güngör E. (2006). 1 Numarall Kütahya Şeriyye Sicili (II. Bölüm) Transkripsiyon ve Kritiği. Yayınlanmamış Yüksek Lisans Tezi. Dumlupınar Üniversitesi, Küyahya 2006.

Gürbüz S. (2009). 296 Numaralı Karaman Şer'iye Sicili Çerçevesinde 1829-1832 Ylllar Arasında Karaman'da Sosyal, İdari ve Hukuki Hayat. Yayımlanmamış Yüksek Lisans Tezi. Selçuk Üniversitesi, Konya 2009.

Hamlacı Y. (2017). "Geç Osmanlı Döneminde Kadın, Doğum ve Çocuk Sağlığı”. Mersin Üniversitesi Tip Fakültesi Lokman Hekim Tip Tarihi ve Folklorik Tip Dergisi 7/1 (2017) 23-27.

Işık S. (2012). "Foucault'da İktidar, Özgürlük ve Direniş ”. Ekev Akademi Dergisi 16/51 (2012) 103-114.

Karaman H.. İslam'ın Işığında Günün Meseleleri. İstanbul 1988.

Karaman H. (2002). Hayatımızdaki İslam. İstanbul 2002.

Karpat K. (2003). Osmanll Nüfusu (1830-1914). İstanbul 2003.

Konan B. (2008). "Osmanlı Devleti'nde Çocuk Düşürme Suçu”. Ankara Üniversitesi Hukuk Fakültesi Dergisi 57/4 (2008) 319-335.

Köse S. O. (2009). "Müslüman Düşüncesinde İnsanın İnsanlığı Sebebiyle Saygınlığının Zirve Noktası". İslam Hukuku Araştırmaları Dergisi 14 (2009) 49-66.

Lewis B. (1996). Modern Türkiye'nin Doğuşu. Ankara 1996.

Özbek N. (2008). Osmanlı İmparatorluğu'nda Sosyal Devlet (1876-1974). İstanbul (2008).

Özemekçi M. İ. (2012). "Modern Devlet ve Tıp; II. Abdülhamit Döneminde Frengi ile Mücadele". Kadın Araştırmaları Dergisi 10 (2012) 83-101.

Öztürk M. "Osmanlı Döneminde Iskat-1 Ceninin Yeri ve Önemi”. Firat Üniversitesi Sosyal Bilimler 
Dergisi 1/1 (1987) 199-208.

Serbestoğlu İ. (2014). “19. Yüzyılda Osmanlı Devleti’nde Nüfus Algısının Değişimi ve Nüfusu Artırma

Çabasında Müfettişlerin Rolü”. Balıkesir Üniversitesi Sosyal Bilimler Enstitüsü Dergisi $17 / 31$ (2014) 255-273.

Shaw S. \& Shaw E. K. (1983). Osmanl İmparatorluğu ve Modern Türkiye. İstanbul 1983.

Somel A. (2002). "Osmanlı Son Döneminde Iskat-1 Cenin Meselesi”. Kebikeç 13 (2002) 65-88.

Yıldız H. (2007). 50 Nolu (H. 1254/M.1838-1839) Tokat Şari'iyye Sicili'nin Transkripsiyonu ve Değerlendirilmesi. Yayımlanmamış Yüksek Lisans Tezi. Erciyes Üniversitesi, Kayseri 2007.

Yücel Y. (1974). Kitab-ı Müstetab. Ankara (1974).

\section{Arşiv Belgeleri}

BOA, A. MKT. DV. 130/61.

BOA, A. MKT. DV. 135/44

BOA, A. MKT. UM 242 / 19

BOA, A.MKT., 242 / 190, 29 L 1272 (3 Temmuz 1856)

BOA, A.MKT.UM, 396 / 66, 23 B 1276 (15 Şubat 1860)

BOA, C. ADL, 108, 9 M 1254 (4 Nisan 1838).

BOA, C. ADL, 80/4825.

BOA, C. ADL, 896, 23 N 1254 (10 Aralık 1838)

BOA, C. ADL., 4825, 27 L 1254 (13 Ocak 1839).

BOA, C. DH, 1790, 5 Za 1254 (20 Ocak 1839)

BOA, C. DH. 1026, Selh-i N 1254 (Kasım 1838)

BOA, C. DH. 6543, 3 Za 1254 (18 Ocak 1839)

BOA, C. DH., 3225, 13 N 1254 (30 Kasım 1838)

BOA, C. SH. 1 / 306, 15 Ş 1254 (3 Kasım 1838)

BOA, C. SH., 566, 13 Za 1254 ( 28 Ocak 1839)

BOA, DH. EUM. AYS-61/48.

BOA, DH. EUM.AYS-61 / 27

BOA, İ. AZN- 66 / 1324 R-01

BOA, İ. DAH. 1185 / 92723

BOA, İ. DAH. 1185 / 92723 ;

BOA, İ. HUS, 121 / 1322. B-52, 14 B 1322 (24 Eylül 1904)

BOA, İ. HUS, 122 / 1322. Ş-11, 4 Şubat 1322 (17 Şubat 1907)

BOA, İ. HUS, 124 / 1322. L-32, 7 L 1322 (15 Aralık 1904)

BOA, İ. MVL, 271 / 10.465, 21 B 1269 (30 Nisan 1853)

BOA, Y. A. HUS, 481 / 76, 16 N 1322 (24 Kasım 1904)

BOA, Y. TPK.AZJ-46 / 19.

BOA., İ. DAH., NO: 95051, 8 Kanun-i Evvel 1308, (20 Aralık 1892) 